\title{
Chemical composition and kraft pulping potential of 12 eucalypt species
}

\author{
Duarte Neiva $^{\mathrm{a}, *}$, Luís Fernandes ${ }^{\mathrm{b}}$, Solange Araújo ${ }^{\mathrm{a}}$, Ana Lourenço ${ }^{a}$, Jorge Gominho ${ }^{\mathrm{a}}$, \\ Rogério Simões ${ }^{\mathrm{b}}$, Helena Pereira ${ }^{\mathrm{a}}$ \\ a Centro de Estudos Florestais, Instituto Superior de Agronomia, Universidade Técnica de Lisboa, Tapada da Ajuda 1349-017 Lisboa, Portugal \\ b Unidade de Materiais Têxteis e Papeleiros, Universidade da Beira Interior, 6200 Covilhã, Portugal
}

\section{A R T I C L E I N F O}

\section{Article history:}

Received 12 August 2014

Received in revised form

19 November 2014

Accepted 9 December 2014

Available online 27 December 2014

\section{Keywords:}

Eucalyptus

Kraft pulp

Chemical composition

Handsheet properties

Fiber properties

\begin{abstract}
A B S T R A C T
Eucalypts are among the most important short-rotation hardwoods, planted worldwide for the pulp and paper industry. Even though the genus comprises over 700 species, only about a dozen species are used for pulping purposes, therefore, showing the potential for diversification. Six-year-old eucalypt trees from 12 species (Eucalyptus botryoides, Eucalyptus camaldulensis, Eucalyptus globulus, Eucalyptus grandis, Corymbia maculata, Eucalyptus ovata, Eucalyptus propinqua, Eucalyptus resinifera, Eucalyptus rudis, Eucalyptus saligna, Eucalyptus sideroxylon, and Eucalyptus viminalis) were analyzed for chemical composition, fiber morphological, pulping and handsheet paper properties to determine their kraft pulping suitability. The 12 species showed substantial differences regarding extractives (6.1-18.9\%), lignin (21.6-30.8\%) and holocellulose content (55.4-70.1\%). The high inter-species variation in chemical composition produced pulps with different yields (between 38.9 and 49.8\%) and degree of delignification (kappa number between 11.6 and 24.2). The combination of these results with the morphological and handsheet properties suggests that E. globulus, E. ovata, E. grandis, E. saligna and E. botryoides have the best overall characteristics for kraft pulping.
\end{abstract}

(c) 2014 Elsevier B.V. All rights reserved.

\section{Introduction}

The Eucalyptus genus comprises over 700 species and hybrids, having originated from natural forests mainly in Australia, but also in Indonesia and Papua New Guinea (Boland et al., 1992; Gonzalez et al., 2011). Due to their rapid growth and wood quality, several of these species were selected and planted worldwide as shortrotation forests for industrial and commercial purpose, initially for pulp and timber but also as renewable source for energy (Knapic et al., 2014; Guo et al., 2002; Ferreira et al., 2013).

Eucalypts are presently among the most important planted hardwoods with 18 million ha in 90 countries under temperate, tropical and subtropical climate conditions (Rockwood et al., 2008). Different species are grown in different countries, according to the adaptability to the weather and soil conditions, with Eucalyptus globulus and Eucalyptus nitens planted in temperate regions of Portugal, Spain, Argentina and Chile, Eucalyptus grandis, Eucalyptus saligna and different hybrids in some South American

\footnotetext{
* Corresponding author. Tel.: +351 213653347; fax: +351 213653338

E-mail address: duarteneiva@isa.ulisboa.pt (D. Neiva).
}

countries, China, South Africa, among others (Forrester et al., 2010), Eucalyptus tereticornis and Eucalyptus camaldulensis in India and Thailand (Terdwongworakul et al., 2005; Kumar et al., 2010), Eucalyptus macarthurii and Eucalyptus smithii in South Africa (Little and Gardner 2003), Eucalyptus regnans, Eucalyptus fastigata and E. nitens in New Zealand (Kibblewhite et al., 2000a). Despite the genus variability, only four species (E. grandis, Eucalyptus urophylla, E. camaldulensis and E. globulus) and their hybrids comprise $80 \%$ of the world plantations (Rockwood et al., 2008).

One of the major uses of eucalypt wood from these shortrotation forests is as raw material for the pulp and paper industry, due to tree fast growth, high pulp yield and high quality short fiberpulp with great physical and optical properties (Kordsachia et al., 1992; Kibblewhite et al., 2000b; Ona et al., 2001; Paavilainen, 2000). In spite of the large variety of eucalypt species only approximately a dozen are used for commercial pulpwood.

Several studies have addressed the pulping ability of the major species currently used in pulp and paper production, but less or no attention has been given to the majority of the species in the genus. A variety of studies is found in the literature, some regarding the morphological and anatomical characteristics of the wood and their relation to pulping and pulp quality (Pirralho et al., 2014; Santos 
et al., 2008 Wimmer et al., 2002, Ona et al., 2001; Kibblewhite, 1999), chemical composition or delignification process (Khristova et al., 2006; Neiva et al., 2014), and comparison between different species on pulping ability (Dutt and Tyagi, 2011; Clark and Hicks, 2003; Kibblewhite et al., 2000b; Foelkel et al., 1975; Barrichelo and Foelkel 1976).

In order to determine the pulp and paper potential of a particular species, several parameters must be studied. It is known that the raw material chemical composition, anatomy, morphology and pulping process and conditions influence the pulp and paper properties, and ultimately determine its quality and appropriate end-use. Pulp yield and degree of delignification (i.e., kappa number) are two key-parameters to describe the wood's kraft pulp potential (Khristova et al., 2006), but alone are insufficient to determine the quality of the pulps produced and the fiber morphological and handsheet properties must also be known.

In the present work, we studied six-year-old Eucalyptus botryoidesEucalyptus botryoides, E. camaldulensis, E. globulus, E. grandis, E. maculata, Eucalyptus ovataEucalyptus ovata, Eucalyptus propinquaEucalyptus propinqua, Eucalyptus resinifera, Eucalyptus rudis, E. saligna, Eucalyptus sideroxylon, Eucalyptus viminalis and compared their wood chemical composition and kraft pulping ability, including fiber morphological and handsheet properties. The results provided information on the pulp and paper potential of these species. The overall objective was to contribute to enlarge the rawmaterial basis for the pulp and paper industry with new potential crops, thereby aligning with goals for increasing diversity in industrial plantations.

\section{Material and methods}

\subsection{Sampling}

Six-year-old eucalypt trees from 12 different species (E. botryoides, E. camaldulensis, E. globulus, E. grandis, E. maculata, E. ovata, E. propinqua, E. resinifera, E. rudis, E. saligna, E. sideroxylon and E. viminalis) were collected from an eucalypt arboretum located in the fields of the School of Agriculture, University of Lisbon (ULisboa), at Tapada da Ajuda, Lisboa, Portugal $\left(38^{\circ} 42^{\prime} \mathrm{N} ; 09^{\circ} 10^{\prime} \mathrm{W}\right)$. Three trees per species were randomly selected from the arboretum. For this study, a $10 \mathrm{~cm}$ thick disc was collected from each tree at stem base, debarked, chipped and screened to an average dimension of $8 \times 4 \times 3 \mathrm{~mm}$. Wood chips from the same species were mixed, homogenized and stored in single lots.

\subsection{Chemical analysis}

For the summative chemical analysis, samples of the 12 homogenized Eucalyptus lots were milled, sieved and the 40-60 mesh fractions used.

Ash content was determined by TAPPI standard method T15 os58. Extractive content (successively in dichloromethane, ethanol and water) was obtained using extraction thimbles in a Soxhlet apparatus for no less than $16 \mathrm{~h}$ for each solvent. The thimbles were oven-dried and weighted after each extraction determining the extractive content by weight variation. Holocellulose, insoluble and soluble lignin were determined in the extractive-free material according to the modified chlorite method, TAPPI standard methods T222 om-88 and UM250 om-83, respectively. All analyses were made in duplicate and average results reported as percentage of initial mass.

Determination of the neutral monosaccharides and acetate content in wood was based on the monomers present in the hydrolysate from the lignin analysis, by separation through a Dionex ICS-3000 High Pressure Ion Chromatography, using an
Aminotrap plus Carbopac SA10 column. The results were reported as percentage of total sugars.

\subsection{Kraft pulping}

Kraft pulping was conducted in stainless steel microdigestors (ca. $100 \mathrm{ml}$ ) under rotation in an oil bath. The pulping conditions were: $10 \mathrm{~g}$ of oven-dry wood, liquid to wood ratio of $4: 1 ; 22 \%$ active alkalinity and $30 \%$ sulfidity as $\mathrm{Na}_{2} \mathrm{O}$, respectively; $165^{\circ} \mathrm{C}$ cooking temperature; five minutes to achieve maximum temperature and 60 min reaction time under isothermal conditions. The solid residue was defibrated and thoroughly washed with hot and cold water until neutral $\mathrm{pH}$. All species were pulped in quadruplicate and reported as average.

\subsection{Estimates of potential pulp production}

For a rough comparison of potential pulp production of the different species at 6 years of age, the wood diameter at breast height (1.3 $\mathrm{m}$ above ground level) was measured with two crossed measurements. Wood basic density was determined as oven dried mass by the saturated volume, using the standard immersion method for volume determination. The potential pulp production was estimated for each species for a reference of 1-m stemwood length by calculating its volume (using the cross-sectional area at breast height), wood mass (using the wood basic density) and kraft pulp yield (KPY) as follows:

Potential pulp production $=$ area at $b . h .\left(\mathrm{m}^{2}\right) \times \operatorname{density}\left(\mathrm{kg} / \mathrm{m}^{3}\right)$

$$
\times 1 \mathrm{~m} \times \mathrm{KPY}
$$

\subsection{Pulp characterization}

Pulping yield was obtained gravimetrically by weighing the oven-dry pulp and reported as percentage of the original wood. Kappa number and polysaccharide degree of polymerization were determined through TAPPI Useful Test Method UM 246 and SCANCM 15:88, respectively. Black liquor total solids, sulfated ash and organic matter content were obtained through TAPPI $625 \mathrm{~cm}-85$ test method. Residual alkali was achieved by titrating a solution with $10 \mathrm{ml}$ of black liquor, $30 \mathrm{ml}$ of water and $20 \mathrm{ml}$ of $\mathrm{BaCl}_{2}(20 \%)$ to $10.5 \mathrm{pH}$.

Pulp fiber morphological properties were determined with MORFI LB01 Fiber Size Analyzer (TECHPAC, France), SchopperRiegler through ISO 5267-1 and WRV (water retention value) by centrifuging samples of wet pulp for $15 \mathrm{~min}$ according to the method reported in Silvy et al. (1968). Handsheets with basic weight $60 \mathrm{~g} / \mathrm{m}^{2}$ from unbeaten kraft pulp were produced and conditioned following ISO 5269-1 and ISO 187 standard norms. Properties (grammage, thickness, bulk, tensile index and tear index) were determined through ISO 5270. Smoothness and air permeability (Bendtsen) measurements were measured with Model 6 Andersson and Sorensen and internal cohesion (Scott-Bond) was measured with a Tester Model B (Precision Scientific Petroleum Instruments, Illinois, USA).

\section{Results and discussion}

\subsection{Chemical analysis}

Table 1 presents the results for the chemical composition of the 12 species of Eucalyptus studied. Ash contents were low and similar for all species (between 0.4 and $0.8 \%$ ) with the exception of E. maculata, which presented a higher value (2.2\%). Ash values are 
Table 1

Chemical composition of 12 species of Eucalyptus as percentage of oven-dried wood.

\begin{tabular}{|c|c|c|c|c|c|c|c|c|c|c|c|c|}
\hline & E. camaldulensis & E. rudis & E. resinífera & E. propinqua & E. sideroxylon & E. botryoides & E. viminalis & E. maculata & E. saligna & E. grandis & E. ovata & E. globulus \\
\hline Ash & 0.8 & 0.7 & 0.6 & 0.4 & 0.4 & 0.6 & 0.6 & 2.2 & 0.8 & 0.4 & 0.6 & 0.6 \\
\hline Total extractives & 18.9 & 14.5 & 8.2 & 8.8 & 13.5 & 9.7 & 6.1 & 10.0 & 10.1 & 6.7 & 6.4 & 6.1 \\
\hline Dichloromethane & 1.1 & 1.2 & 0.9 & 0.6 & 0.7 & 0.4 & 0.8 & 1.1 & 0.9 & 0.7 & 0.9 & 0.4 \\
\hline Ethanol & 14.8 & 10.7 & 5.2 & 6.7 & 10.8 & 5.8 & 2.9 & 6.5 & 7.2 & 4.2 & 2.8 & 2.3 \\
\hline Water & 3.0 & 2.7 & 2.1 & 1.5 & 2.0 & 3.5 & 2.3 & 2.4 & 2.0 & 1.8 & 2.7 & 3.4 \\
\hline Total lignin & 24.0 & 26.8 & 30.8 & 29.9 & 26.6 & 27.1 & 26.8 & 21.6 & 26.6 & 27.8 & 26.0 & 24.8 \\
\hline Klason lignin & 21.8 & 23.4 & 28.1 & 27.7 & 23.3 & 24.3 & 23.2 & 18.5 & 23.7 & 25.1 & 22.2 & 21.1 \\
\hline Soluble lignin & 2.3 & 3.5 & 2.8 & 2.2 & 3.2 & 2.8 & 3.6 & 3.1 & 2.9 & 2.7 & 3.8 & 3.7 \\
\hline Holocellulose & 55.4 & 59.0 & 61.0 & 62.7 & 61.1 & 64.7 & 68.1 & 64.8 & 64.2 & 66.8 & 68.3 & 70.1 \\
\hline $1 \% \mathrm{NaOH}$ solubles & 29.7 & 23.4 & 22.1 & 18.9 & 23.3 & 18.3 & 17.8 & 20.3 & 21.5 & 17.1 & 19.8 & 17.4 \\
\hline
\end{tabular}

similar to previous reports for some of these species such as E. globulus between 0.3 and 0.5\% (Neiva et al., 2014; Malik et al., 2004; Pereira, 1988; Miranda and Pereira, 2002; Pereira et al., 2011), E. camaldulensis 0.4 and 1.3\% (Khristova et al., 2006; Dutt and Tyagi, 2011), E grandis 0.3-2.9\% (Dutt and Tyagi, 2011; Malik et al., 2004), E. saligna 0.2 and $0.3 \%$ (Foelkel et al., 1975) and E. maculata $0.5 \%$ (Foelkel et al., 1975). Low ash content is desirable since it negatively affects many aspects of the pulping process, such as alkali consumption, black liquor recovery operations and material handling (Dutt and Tyagi, 2011). Regarding the extractives content, results showed a large variability between species with $E$. camaldulensis (18.9\%) having more than three times the lowest values obtained for E. viminalis and E. globulus (6.1\%). Apolar extractives represent a small fraction of the total extractives content with little variability between species. Wood extractives, principally the aliphatic compounds, have a detrimental effect in pulp yield, kappa number and bleaching (Lourenço et al., 2010; Gominho et al., 2001; Baptista et al., 2006) causing also pitch problems in the pulp or paper mill production (Hillis and Sumimoto, 1989; Ogunwusi, 2012). The values found in the literature are lower than the ones presented in this manuscript for all the species mainly because we used an exhaustive and sequential extraction with three solvents with different degrees of polarity. For instance the result obtained for $E$. camaldulensis is above the reported values e.g., Moussaouiti et al. (2012) presented $6.7 \%$ and $6.6 \%$ of hot water and ethanol-toluene extractives, respectively, and Fatehi et al. (2010) reported $8.9 \%$ of ethanol-benzene extractives.

Lignin content for the different species showed a variation in absolute values of $9.2 \%$, from highest (E. resinifera, $30.8 \%$ ) to lowest (E. maculata, 21.6\%) with 85-93\% of the total lignin being insoluble lignin (Klason lignin). Barrichelo and Foelkel (1976) presented lignin contents similar to ours for 5-year-old E. saligna (26.3\%) and 7-year-old E. grandis (26.3\%) and higher values for 11-yearold E. viminalis (23.2\%). Dutt and Tyagi (2011) determined higher lignin values for $E$. grandis and E. camaldulensis of $29.3 \%$ and $33.2 \%$ respectively for 4-year-old specimens, and Foelkel et al. (1975) determined $17.5 \%$ Klason lignin for E. maculata, which is similar to the value found in this work.

Total amount of polysaccharides (measured as holocellulose) for these species was between 55.4-70.1\%. High holocellulose content in wood is desirable and is expected to be positively correlated to pulp yield. E globulus showed the highest value of holocellulose, with $E$. viminalis and E. ovata also with similar contents $(68.1 \%$ and $68.4 \%$, respectively). On the lower side, E. camaldulensis and E. rudis only had $55.4 \%$ and $59 \%$ holocellulose content, respectively.

Table 2 presents the carbohydrates and acetates composition for the 12 eucalypt species. All species have small amounts of arabinose and galactose and the main difference resides in the relative proportion between glucose (related mostly to cellulose) and xylose (related only to hemicelluloses). Acetates are a resulting product from the depolymerization of the hemicelluloses and the hydrolysis of the acetyl groups (Spiridon and Popa, 2004).

\subsection{Kraft pulping}

Table 3 reports the pulp and black liquor results from the cooking of the different eucalypts. The relatively high alkali charge used was due to high extractives and lignin content presented by some of the species studied. Temperature, reaction time and sulfidity values were typical values used in industrial eucalypt pulping to obtain pulps with kappa number below 17 (as targeted by the industry). The use of the same reaction conditions may result in excessive cooking for some eucalypts while others may still retain high amounts of residual lignin. Therefore, species pulped below kappa number 17 could be improved if the reaction conditions were milder since harsher than necessary reaction conditions lead to lower yield and higher carbohydrate degradation. As expected, the wood from the different species produced pulps with different characteristics regarding yield, kappa number and degree of polymerization. The black liquors also presented different attributes although in a less pronounced way. The pulp yield achieved under the same reaction conditions showed a large variation among species, between $38.9 \%$ and $49.8 \%$ for E. camaldulensis and E. globulus, respectively. These yields are directly related to the amount of holocellulose present in the wood, with higher holocellulose content resulting in higher pulp yield $\left(R^{2}=0.84\right)$. Extractive content showed a negative influence in yield but we found a poor relation between these two parameters $\left(R^{2}=0.58\right)$. No relations were found regarding lignin content and yield or kappa number.

E. ovata showed a great resemblance to E. globulus both in yield and kappa number, and good results were also achieved by $E$. grandis, E. saligna, E viminalis and $E$ sideroxylon. On the lower side of the ranking lie E. camaldulensis, E. rudis, E resinifera and E. propinqua due to low yield and high kappa number. E. botryoides and $E$ maculata produced pulps with average yields and higher kappa numbers, which will increase chemical demand and harsher conditions upon bleaching. Although having the lowest wood lignin content and average amount of extractives E. maculata produced a pulp with the highest amount of residual lignin, which might partially be explained by the high density of this $\operatorname{wood}\left(767 \mathrm{~kg} / \mathrm{dm}^{3}\right.$, Table 4), leading to poorer cooking liquor impregnation (Clark and Hicks, 2003). Such results clearly show that the chemical composition alone will not explain the ease of delignification, with several studies in the literature pointing to other important variables such as wood density or type of lignin (S/G) present in its structure (González-Vila et al., 1999; Lourenço et al., 2013; Foelkel, 2009).

In the literature, values for E. globulus kraft pulping ranged from 44-56\% yield and 11-20 kappa numbers (Neiva et al., 2014; Wimmer et al., 2002; Ona et al., 2001; Barrichelo and Foelkel, 1976; Santos et al., 2008) for a variety of experimental conditions and tree 
Table 2

Monosaccharides and acetates percentage in relation to total sugars for 12 species of Eucalyptus.

\begin{tabular}{|c|c|c|c|c|c|c|c|c|c|c|c|c|}
\hline & E. camaldulensis & E. rudis & E. resinífera & E. propinqua & E. sideroxylon & E. botryoides & E. viminalis & E. maculata & E. saligna & E. grandis & E. ovata & E. globulus \\
\hline Arabinose & 1.2 & 1.1 & 1.2 & 1.1 & 1.1 & 1.1 & 1.1 & 1.1 & 1.1 & 1.1 & 1.0 & 1.1 \\
\hline Galactose & 1.8 & 2.2 & 2.4 & 2.1 & 2.2 & 1.1 & 1.1 & 1.1 & 2.3 & 1.1 & 1.0 & 1.1 \\
\hline Glucose & 62.3 & 65.5 & 63.5 & 68.6 & 61.0 & 68.2 & 63.1 & 63.3 & 65.0 & 68.0 & 63.6 & 64.3 \\
\hline Xylose & 26.4 & 23.5 & 24.9 & 21.6 & 27.7 & 22.3 & 26.1 & 26.1 & 23.8 & 22.7 & 28.2 & 25.4 \\
\hline Acetates & 8.3 & 7.7 & 8.0 & 6.6 & 7.9 & 7.3 & 8.5 & 8.5 & 7.8 & 7.1 & 6.1 & 8.1 \\
\hline
\end{tabular}

Table 3

Pulp and black liquor characterization for the cooking of 12 species of Eucalyptus.

\begin{tabular}{|c|c|c|c|c|c|c|c|}
\hline & \multicolumn{3}{|l|}{ Pulp } & \multicolumn{4}{|l|}{ Black liquor } \\
\hline & Yield (\%) & Kappa number & DP & Residual alkali (\% as $\mathrm{Na}_{2} \mathrm{O}$ ) & Solids (\%m/m) & Sulphated ash (\% as $\mathrm{NaOH})$ & Organic matter (\%) \\
\hline E. camaldulensis & $38.9 \pm 0.8$ & $20.1 \pm 1.5$ & $3596 \pm 242$ & $1.23 \pm 0.15$ & $19.3 \pm 0.5$ & $30.1 \pm 0.2$ & $69.9 \pm 0.2$ \\
\hline E. rudis & $41.3 \pm 0.6$ & $19.3 \pm 0.4$ & $3251 \pm 391$ & $1.76 \pm 0.13$ & $18.2 \pm 0.5$ & $30.4 \pm 0.3$ & $69.6 \pm 0.3$ \\
\hline E. resinifera & $41.9 \pm 0.8$ & $17.2 \pm 0.6$ & $3236 \pm 377$ & $1.93 \pm 0.17$ & $19.0 \pm 0.7$ & $30.2 \pm 0.4$ & $69.8 \pm 0.4$ \\
\hline E. propinqua & $42.2 \pm 0.2$ & $20.3 \pm 0.8$ & $3321 \pm 281$ & $2.17 \pm 0.04$ & $18.5 \pm 0.7$ & $31.0 \pm 0.2$ & $69.0 \pm 0.2$ \\
\hline E. sideroxylon & $43.4 \pm 0.2$ & $14.9 \pm 0.6$ & $3211 \pm 93$ & $2.33 \pm 0.20$ & $17.9 \pm 0.3$ & $31.4 \pm 0.3$ & $68.6 \pm 0.3$ \\
\hline E. botryoides & $44.3 \pm 0.3$ & $17.1 \pm 0.6$ & $3785 \pm 324$ & $1.72 \pm 0.16$ & $18.7 \pm 0.4$ & $30.6 \pm 0.8$ & $69.4 \pm 0.8$ \\
\hline E. viminalis & $44.2 \pm 0.3$ & $14.8 \pm 0.4$ & $3183 \pm 256$ & $2.34 \pm 0.16$ & $17.8 \pm 0.2$ & $31.4 \pm 0.3$ & $68.6 \pm 0.3$ \\
\hline E. maculata & $44.4 \pm 0.4$ & $24.2 \pm 0.7$ & $3552 \pm 99$ & $2.60 \pm 0.02$ & $17.9 \pm 0.6$ & $33.1 \pm 0.3$ & $66.9 \pm 0.3$ \\
\hline E. saligna & $44.6 \pm 0.4$ & $14.1 \pm 0.8$ & $2937 \pm 255$ & $2.34 \pm 0.08$ & $17.9 \pm 0.7$ & $32.0 \pm 0.3$ & $68.0 \pm 0.3$ \\
\hline E. grandis & $45.6 \pm 0.3$ & $14.5 \pm 0.4$ & $3133 \pm 145$ & $2.50 \pm 0.13$ & $18.0 \pm 0.3$ & $31.4 \pm 0.1$ & $68.6 \pm 0.1$ \\
\hline E. ovata & $48.6 \pm 0.1$ & $13.2 \pm 0.6$ & $3069 \pm 360$ & $2.58 \pm 0.08$ & $17.5 \pm 0.9$ & $33.3 \pm 0.5$ & $66.7 \pm 0.5$ \\
\hline E. globulus & $49.8 \pm 0.2$ & $11.6 \pm 0.6$ & $3188 \pm 248$ & $2.93 \pm 0.15$ & $17.2 \pm 0.2$ & $33.1 \pm 0.8$ & $66.9 \pm 0.8$ \\
\hline
\end{tabular}

ages. Dutt and Tyagi (2011), Ona et al. (2001) and Rahmati et al. (2007) found, for $E$ camaldulensis values in the range of 37.3-51.8\% and 20-34 for yield and kappa number, respectively. Values for $E$. saligna (47-49\% yield, 15-19 kappa number), E. grandis (46-50\% yield, 14-21 kappa number), E. viminalis (44-51\% yield, 11-18 kappa number), E. propinqua (45\% yield, 24 kappa number) and $E$. maculata (45-52 yield, 16-19 kappa number) were found in other studies (Clark and Hicks, 2003; Dutt and Tyagi, 2011; Foelkel, 1974; Foelkel et al., 1975; Barrichelo and Foelkel, 1976).

The residual alkali in the black liquor is an important parameter that relates to the extent of chemical reagents consumed in both delignification and extractives/carbohydrates extraction and degradation reactions. In the present case, the effective alkali used at the beginning of the pulping was $18.7 \%$ as $\mathrm{Na}_{2} \mathrm{O}$ in relation to the eucalypt wood. As can be seen in Table 3, E. camaldulensis almost exhausted the reagents; and therefore, even if the reaction time could be extended little profit would be obtained. The same applies to some extent for E. rudis, E. resinifera, E. propinqua and E. botryoides, meaning that under these reaction conditions it would be difficult to achieve pulps with lower kappa numbers. On the other hand for E. maculata a higher reaction time could have continued the delignification and therefore lower the kappa number but at the expense of a decrease in pulp yield.

High extractive content in wood leads to higher chemical demand; and therefore, it was expected that E. sideroxylon $(13.5 \%$ extractives) would have worst results regarding kappa number and residual alkali in relation to some other species. For the pulps that attained low kappa numbers and still maintained some effective alkali, continuing the reaction would probably be detrimental since the selectivity decreases with the extent of delignification, leading to the loss of carbohydrates polymers rather than lignin.

Since high content of solids in the black liquor results in higher adiabatic combustion temperature in the recovery boiler (Dutt and Tyagi, 2011), the higher the original solid content of the black liquor the less energy demand is needed at the evaporation sequence to reach the optimal consistency to burn. From the results, we can infer that the lower the yield the higher the percentage of solids and organic matter in the liquor. For example pulp yields from E. camaldulensis (38.9\%) and E. globulus (49.8\%) correspond to the highest and lowest amount of solid content in respective black liquors (19.3\% and $17.2 \%$, respectively).

\subsection{Potential pulp production}

Table 4 shows the average wood diameter and wood basic density and an estimated potential pulp production for each eucalypt species (estimated for a 1-m longer log of 6-year-old trees). Wood basic density for commercial pulpwoods is usually within $400-600 \mathrm{~kg} / \mathrm{m}^{3}$ although higher values can be accepted for specific papers (Clark and Hicks, 2003). All the species tested were within this interval, except for E. propinqua and E. maculata with higher values. E. camaldulensis presented the lowest diameter and pulp yield and therefore, was the lowest ranked in pulp production estimates. At the highest position of the ranking was E. globulus. E. maculata, due to the high wood density, obtained values above other woods with better pulping yields. It must be stressed that the different tree growth between species is only indicative for the edaphoclimatic conditions of this arboretum. Therefore low species performance

Table 4

Tree diameter, wood density and comparative pulp production estimates per unit ( $\mathrm{m}) \log$ length ( $\left.\mathrm{kg} \mathrm{m}^{-1}\right)$ at 6 years of age for the 12 species of Eucalyptus.

\begin{tabular}{|c|c|c|c|c|c|c|c|c|c|c|c|c|}
\hline & E. camaldulensis & E. rudis & E. resinífera & E. propinqua & E. sideroxylon & E. botryoides & E. viminalis & E. maculata & E. saligna & E. grandis & E. ovata & E. globulus \\
\hline Diameter $(\mathrm{cm})$ & 10.2 & 13.0 & 16.3 & 16.5 & 16.2 & 24.0 & 17.4 & 18.0 & 18.5 & 17.0 & 20.3 & 23.1 \\
\hline $\begin{array}{l}\text { Density } \\
\qquad\left(\mathrm{kg} / \mathrm{m}^{3}\right)\end{array}$ & 500 & 507 & 400 & 629 & 565 & 476 & 501 & 767 & 451 & 503 & 465 & 577 \\
\hline $\begin{array}{l}\text { Potential pulp } \\
\text { production } \\
\left(\mathrm{kg} \mathrm{m}^{-1}\right) \text { in } 6 \\
\text { years }\end{array}$ & 62 & 86 & 86 & 138 & 125 & 159 & 121 & 193 & 117 & 123 & 144 & 209 \\
\hline
\end{tabular}


Table 5

Morphological properties of pulp fibers from 12 Eucalyptus species.

\begin{tabular}{|c|c|c|c|c|c|c|c|c|c|c|c|c|}
\hline & E. camaldulensis & E. rudis & E. resinífera & E. propinqua & E. sideroxylon & E. botryoides & E. viminalis & E. maculata & E. saligna & E. grandis & E. ovata & E. globulus \\
\hline Fibers (millions/g) & 28.9 & 30.1 & 32.4 & 23.9 & 32.8 & 26.1 & 41.4 & 18.3 & 24.8 & 25.0 & 32.0 & 24.2 \\
\hline $\begin{array}{l}\text { Length }(\mu \mathrm{m}) \text {, } \\
\text { weighted in } \\
\text { length }\end{array}$ & 569 & 626 & 629 & 614 & 568 & 719 & 598 & 748 & 708 & 759 & 608 & 727 \\
\hline Width $(\mu \mathrm{m})$ & 19.7 & 19.2 & 19.3 & 18.8 & 16.8 & 19.6 & 18.4 & 18.0 & 19.6 & 18.9 & 19.4 & 18.2 \\
\hline $\begin{array}{l}\text { Coarseness } \\
\qquad(\mathrm{mg} / 100 \mathrm{~m})\end{array}$ & 6.8 & 6.0 & 5.7 & 7.6 & 5.9 & 6.3 & 4.6 & 8.4 & 6.6 & 6.1 & 5.9 & 6.7 \\
\hline Kinked fibers (\%) & 21.9 & 19.2 & 17.6 & 21.8 & 20.4 & 26.3 & 21.4 & 27.1 & 21.0 & 24.3 & 21.5 & 33.1 \\
\hline Curl (\%) & 5.4 & 5.2 & 5.0 & 5.5 & 5.3 & 6.1 & 5.3 & 6.2 & 5.3 & 5.7 & 5.5 & 6.8 \\
\hline $\begin{array}{l}\text { Fine elements \% in } \\
\text { area }\end{array}$ & 16.2 & 15.1 & 12.6 & 18.5 & 14.4 & 12.7 & 9.1 & 15.6 & 12.2 & 10.3 & 13.5 & 13.0 \\
\hline
\end{tabular}

regarding diameter growth might be due to inadaptation and these rankings should be considered with caution and certainly should not be generalized to other environments.

\subsection{Pulp morphological properties}

Table 5 shows the morphological properties of the fibers obtained by the kraft pulping of the 12 different eucalypt species. Eucalypt pulp fibers are considered short fibers, normally with length between 0.6 and $0.85 \mathrm{~mm}$ (Foelkel, 2007). In the present case, most of the species yielded fibers within those values with slightly shorter fibers for E. camaldulensis and E. sideroxylon. The fiber width was relatively similar between species varying between 16.8 and $19.7 \mu \mathrm{m}$. Malik et al. (2004) reported values of fiber length (760 $\mu \mathrm{m}$ and $840 \mu \mathrm{m})$ and fiber width $(15 \mu \mathrm{m}$ and $19 \mu \mathrm{m})$ for E. globulus and E. grandis, respectively. Hicks and Clark (2001) reported fiber length values between 570 and $700 \mu \mathrm{m}$ for E. globulus, 510 and $680 \mu \mathrm{m}$ for E. viminalis and $840 \mu \mathrm{m}$ for E. maculata. Coarseness is a parameter related to the fiber wall thickness, fiber width, cell wall porosity and solid removal in cooking. The highest value was in E. maculata $(8.4 \mathrm{mg} / 100 \mathrm{~m})$ and the lowest in E. viminalis $(4.6 \mathrm{mg} / 100 \mathrm{~m})$. Fiber population is inversely proportional to fiber coarseness and fiber length; the good correlation $\left(R^{2}=0.82\right)$, highlight the importance of the fiber coarseness on the fiber population. These three fiber parameters have an important impact on apparent paper density (Kibblewhite and Riddell, 2000).

Normally the lower the kink and curl fiber percentage the higher the rigidity, coarseness and fiber width. In this specific case we did not find any correlation between those variables and coarseness. The only value found in the literature to compare with our results was for E. globulus industrial pulp (28.7\% kinked fibers and $7.28 \%$ curl) by Baptista et al. (2014), which was very similar to ours.

\subsection{Handsheet properties}

Handsheet properties for the 12 eucalypt pulps produced are presented in Table 6 . These properties relate to the unbeaten unbleached pulps obtained under the same delignification conditions, as explained previously. The freeness of the eucalypt pulp suspensions, presented through the Schopper-Riegler degree ( $\left.{ }^{\circ} \mathrm{SR}\right)$ showed a great variation between species, with E. maculata (16) and $E$. resinifera (27) showing the highest and lowest drainability. According to Foelkel (2007), the unbeaten pulp initial ${ }^{\circ}$ SR should be between 16 and 24, which was the case for the different pulps with $E$. rudis and E. resinifera falling a bit over.

Water retention value (WRV) is a combined effect of physical and chemical properties that measures the pulps' water affinity. This property is important since it is related to the paper machine runnability, affecting dewatering, drainage, drying and consequently the quality of the paper and the cost to produce it. Too high WRV also limits the beating process that increases the strength properties of the pulp. A range of WRV for previously

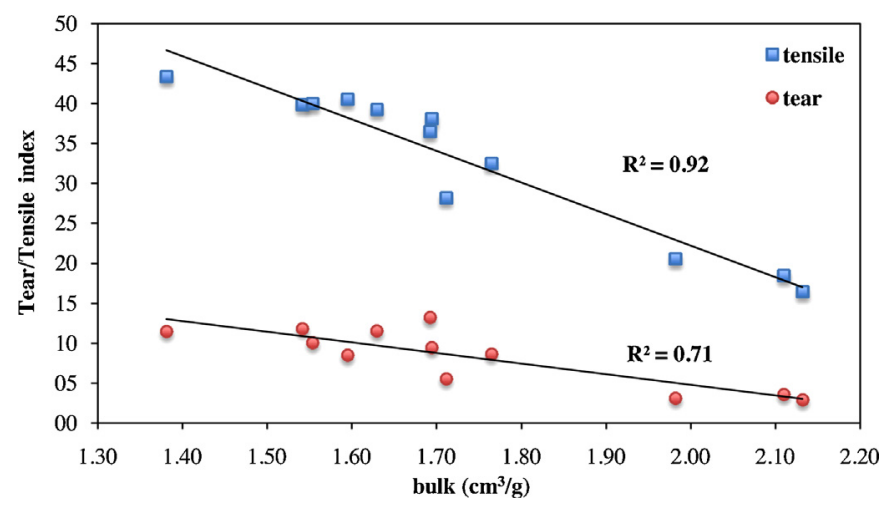

Fig. 1. Relation between bulk and tear/tensile index for the 12 species of Eucalyptus.

dried unbeaten eucalypt pulps was reported between 100 and $130 \%$ (Foelkel, 2007). In the present study, E. camaldulensis, E rudis, E. resinifera and $E$. ovata pulps achieved higher values.

Regarding ISO brightness, E. globulus and E. viminalis showed the highest values (41\%) while on the lower side, E. camaldulensis showed only $29 \%$. The higher the residual lignin and extractives content the lower ISO brightness is expected since these components are the ones which give the color to the pulp. Oudia et al. (2004) found similar results for E. globulus (40-45\%) in pulps with kappa number between 16 and 18. Khristova et al. (2006) reported for E. camaldulensis pulps with kappa number 24.4 ISO brightness of $25.9 \%$.

Handsheet bulk is considered a critical property when assessing fiber type for different pulp and paper grades. It is a measure of fiber packing density and web structural organization (Kibblewhite, 1999; Kibblewhite and Riddell, 2000; Kibblewhite et al., 2000a). Higher bulk indicates lower fiber conformity and a more open structure of the fiber matrix (Ferreira et al., 2013), resulting in lesser fiber bonding ability, lower paper strength and higher porosity. The correlation between this property with tensile and tear index is demonstrated in Fig. 1. Three pulps (E. propinqua, E. sideroxylon and $E$. maculata) showed the highest bulk and consequently the lowest tear index (between 2.9 and $3.6 \mathrm{mN} . \mathrm{m}^{2} / \mathrm{g}$ ) and tensile index $(16.4-18.5 \mathrm{Nm} / \mathrm{g})$. Although it is possible to increase the strength of the pulp by refining, the original values suggest a bad pulp strength behavior in comparison with the other species. For E. propinqua, E. sideroxylon and E. maculata, handsheets' air permeability also achieved the highest values (1883-2490 ml/min). All other species showed lower bulk values and higher strength properties.

A typical data sheet with average results for the pulping of $E$. globulus (with kappa number between 12 and 17) obtained by a Portuguese pulp and paper mill showed an initial freeness of $18^{\circ} \mathrm{SR}$, tear index $4.4 \mathrm{mN} \mathrm{m}^{2} / \mathrm{g}$ and tensile index $32.9 \mathrm{~N} \mathrm{~m} / \mathrm{g}$. Comparing the strength properties between this typical data with our result, we can see that, with the exception of E. propinqua. E. sideroxylon and $E$. 
Table 6

Handsheet properties for the 12 species of Eucalyptus.

\begin{tabular}{|c|c|c|c|c|c|c|c|c|c|c|c|c|}
\hline & E. camaldulensis & E. rudis & E. resinífera & E. propinqua & E. sideroxylon & E. botryoides & E. viminalis & E. maculata & E. saligna & E. grandis & E. ovata & E. globulus \\
\hline${ }^{\circ} \mathrm{SR}$ & 24.0 & 26.0 & 27.0 & 20.5 & 20.5 & 21.0 & 24.0 & 16.0 & 19.5 & 21.5 & 24.5 & 19.0 \\
\hline WRV (\%) & 137 & 137 & 133 & 114 & 107 & 127 & 126 & 99 & 118 & 113 & 133 & 112 \\
\hline Grammage $\left(\mathrm{g} / \mathrm{m}^{2}\right)$ & 63.2 & 62.7 & 64.7 & 63.7 & 64.1 & 63.8 & 62.2 & 63.7 & 60.0 & 64.1 & 64.1 & 63.6 \\
\hline Thickness (mm) & 0.108 & 0.100 & 0.100 & 0.134 & 0.127 & 0.104 & 0.086 & 0.136 & 0.102 & 0.108 & 0.100 & 0.112 \\
\hline Bulk $\left(\mathrm{cm}^{3} / \mathrm{g}\right)$ & 1.71 & 1.59 & 1.54 & 2.11 & 1.98 & 1.63 & 1.38 & 2.13 & 1.69 & 1.69 & 1.55 & 1.76 \\
\hline $\begin{array}{l}\text { Air permeability } \\
(\mathrm{mL} / \mathrm{min})\end{array}$ & 656 & 447 & 365 & 2029 & 1883 & 700 & 376 & 2490 & 1143 & 1171 & 350 & 1500 \\
\hline $\begin{array}{l}\text { Smoothness } \\
(\mathrm{mL} / \mathrm{min})\end{array}$ & 779 & 640 & 526 & 823 & 577 & 238 & 452 & 230 & 1047 & 1158 & 187 & 443 \\
\hline $\begin{array}{l}\text { Tear index } \\
\quad\left(\mathrm{mN} \mathrm{m}^{2} / \mathrm{g}\right)\end{array}$ & 5.6 & 8.5 & 11.8 & 3.6 & 3.1 & 11.6 & 11.5 & 2.9 & 9.4 & 13.2 & 10.1 & 8.6 \\
\hline Scott bond $\left(\mathrm{J} / \mathrm{m}^{2}\right)$ & 192 & 166 & 181 & 90 & 72 & 142 & 166 & 63 & 103 & 122 & 169 & 116 \\
\hline $\begin{array}{l}\text { Tensile index } \\
(\mathrm{Nm} / \mathrm{g})\end{array}$ & 28.1 & 40.5 & 39.8 & 18.5 & 20.6 & 39.3 & 43.4 & 16.4 & 38.1 & 36.5 & 40.0 & 32.5 \\
\hline ISO brightness (\%) & 29 & 37 & 33 & 32 & 36 & 33 & 41 & 32 & 36 & 36 & 40 & 41 \\
\hline
\end{tabular}

maculata, all other species showed better tear index and similar or higher tensile index. Regarding freeness, all laboratory pulps except E. maculata $\left(16^{\circ} \mathrm{SR}\right)$ had a higher value of ${ }^{\circ} \mathrm{SR}$ than the industrial pulp, certainly due to the higher fines content of the laboratorial pulps.

These results suggest that handsheet properties of E. camaldulensis, E. botryoides, E. viminalis, E. saligna, E. grandis, E. ovata and E. globulus are approximate to the unbeaten unbleached average industrial sheet properties of E. globulus commercial used for producing printing and writing papers.

Low bulk, high numbers of short fibers of low collapse resistance and coarseness are unsuitable for most eucalypt kraft end uses, namely office papers (Kibblewhite, 1999; Kibblewhite and McKenzie, 1999). E. viminalis, with the highest amount of fibers per gram (41.4 million), lowest coarseness ( $4.6 \mathrm{mg} / 100 \mathrm{~m}$ ) and bulk $\left(1.38 \mathrm{~cm}^{3} / \mathrm{g}\right)$ appears therefore to be unsuitable for office papers production, at least under the present reaction conditions.

To produce highly porous and tissue papers, pulp needs to have specific characteristics such as: low fiber population, high coarseness, low fines, low bonding ability, low water retention value and low unbeaten pulp Schopper Riegler (Foelkel, 2009). In this study, E. maculata, presented the lowest fiber population (18.3 million/g), highest coarseness $(8.4 \mathrm{~g} / 100 \mathrm{~m})$, low bonding ability (lowest values for Scott bond, tear and tensile index), lowest water retention value (99\%) and lowest Schopper Riegler for unbeaten pulp thus, making it an ideal candidate for this end use. E. propinqua also appears to have good characteristics for this type of paper.

\section{Conclusions}

The 12 Eucalyptus species analyzed in this study differed substantially from each other in terms of chemical composition, kraft cooking, fiber morphology and handsheet characteristics. Overall our results indicate that among the species analyzed E. globulus presented the best results in terms of combined kraft and handsheet properties. This result is not surprising considering that E. globulus is one of the most widely used species in temperate regions for the pulp and paper industry. Nevertheless, our analysis also showed that under the same circumstances (edaphoclimatic tree growth conditions and wood pulping parameters), other species such as E. ovata, E. grandis, E. saligna and E. botryoides also perform well regarding printing and writing end use and $E$. maculata and $E$ propinqua regarding tissue paper end use. Such species can potentially be used as alternatives (or even first choice) in areas where ecological or operational constraints rule out the plantation of $E$. globulus. On the other hand, E. camaldulensis, E. rudis, E. resinifera, E. sideroxylon and $E$ viminalis presented low pulping or paper potential under the pulping conditions tested here. However tailoring the pulping conditions to the specific species could improve its performance.

\section{Acknowledgements}

We are grateful to Dr. Paula Soares for providing the samples and the information about the trial, which was sponsored by CELPA - Associação da Indústria Papeleira (Portuguese Pulp and Paper Industry Association). Financial support for the laboratory analyses was given by research funding of FCT (Fundação para a Ciência e a Tecnologia) to CEF (Centro de Estudos Florestais) under its Strategic Project (Pest-OE/AGR/UI0239/2014), and two projects (PTDC/AGR-CFL/110419/2009 and PTDC/AGRFOR/3872/2012). The authors also wish to acknowledge the Federal University of Viçosa, Capes (Coordination for the Development of Higher Level Personnel) and CNPq (National Council for Scientific and Technological Development) for financial support.

\section{References}

Baptista, C., Belgacem, M.N., Duarte, A.P., 2006. The effect of wood extractives on pulp properties of Pinus pinaster kraft pulp. Appita J. 59 (4), 311-316.

Baptista, P., Costa, A.P., Simões, R., Amaral, M.E., 2014. Ailanthus altissima, an alternative fibre source for papermaking. Ind. Crop. Prod. 52, 32-37.

Barrichelo, L.E.G., Foelkel, C.E.B., 1976. Estudos para produção de celulose sulfato de seis espécies de eucalipto. IPEF 12, 77-95.

Boland, D.J., Brooker, M.I.H., Chippendale, G.M., Hall, N., Hyland, B.P.M., Johnston, R.D., Kleinig, D.A., Turner, J.D., 1992. Forest Trees of Australia over 200 of Australia's Most Important Native Trees. Described \& Illustrated. Commonwealth Scientific and Industrial Research Organization (CSIRO), Australia.

Clark, N.B., Hicks, C.C., 2003. Evaluation of the pulpwood quality of 13 lesser-known eucalypt species. Appita J. 52 (3), 203-2012.

Dutt, D., Tyagi, C.H., 2011. Comparison of various eucalyptus species for their morphological chemical, pulp and paper making characteristics. Indian J. Chem. Technol. 18, 145-151.

Fatehi, P., Arabshahi, S., Ziaee, Z., Malinen, R.O., Ni, Y., 2010. Simulating the impact of kraft pulping and bleaching parameters on Eucalyptus camaldulensis pulp properties using Matlab. Can. J. Chem. Eng. 88 (3), 455-461, http://dx.doi.org/10.1002/cjce.20299.

Ferreira, P.J.T., Gamelas, J.A.F., Carvalho, M.G.V.S., Duarte, G.V., Canhoto, J.M.P.L., Passas, R., 2013. Evaluation of the papermaking potential of Ailanthus altissima. Ind. Crop. Prod. 42 (1), 538-542, http://dx.doi.org/10.1016/j.indcrop.2012.06.030.

Foelkel, C.E.B., 1974. Rendimento em celulose sulfato de Eucalyptus spp em função do grau de deslignificação e da densidade da madeira. IPEF 9, 61-77.

Foelkel, C.E.B., Barrichelo, L.E.G., Milanez, A.F., 1975. Estudo comparativo das madeiras de Eucalyptus saligna, E. paniculata, E. citridora, E. maculata e E. tereticornis para produção de celulose sulfato. IPEF 10, 17-37.

Foelkel, C., 2007. The eucalyptus fibers and the kraft pulp quality requirements for paper manufacturing. Eucalyptus Online Book \& Newsletter http://www.eucalyptus.com.br/capitulos/ENG03_fibers.pdf

Foelkel, C., 2009. Papermaking properties of Eucalyptus trees, woods and pulp fibers. Eucalyptus Online Book \& Newsletter, http://www. eucalyptus.com.br/eucaliptos/ENG14.pdf

Forrester, D.I., Medhurst, J.L., Wood, M., Beadle, C.L., Valencia, J.C., 2010. Growth and physiological response to silviculture for producing solid-wood products 
form Eucalyptus plantations: an Australian perspective. For. Ecol. Manage. 259 (9), 1819-1835, http://dx.doi.org/10.1016/j.foreco.2009.08.029.

Gominho, J., Figueira, J., Rodrigues, J.C., Pereira, H., 2001. Within-tree variation of heartwood, extractives and wood density in the eucalypt hybrid urograndis (Eucalyptus grandis $\times$ E. urophylla). Wood Fiber Sci. 33 (1), 3-8

González-Vila, F.J., Almendros, G., del Rio, J.C., Martín, F., Gutiérrez, A., Romero, J., 1999. Ease of delignification assessment of wood from different Eucalyptus species by pyrolysis (TMAH)-GC/MS and CP/MAS ${ }^{13} \mathrm{C}-\mathrm{NMR}$ spectrometry. J. Anal. Appl. Pyrol. 49, 295-305.

Gonzalez, R., Treasure, T., Wright, J., Saloni, D., Phillips, R., Abt, R., Jameel, H., 2011. Exploring the potential of Eucalyptus for energy production in the Southern United States: financial analysis of delivered biomass. Part I. Biomass Bioenerg. 35 (2), 755-766, http://dx.doi.org/10.1016/j.biombioe.2010.10.011.

Guo, L., Sims, R., Horne, D., 2002. Biomass production and nutrient cycling in Eucalyptus short rotation energy forests in New Zeland. I: biomass and nutrient accumulation. Bioresour. Technol. 85 (3), 273-283, http://dx.doi.org/10.1016/S0960-8524(02)118-9.

Hicks, C.C., Clark, N.B., 2001. Pulpwood quality of thirteen eucalypt species with potential for farm forestry. RIRDC 01/164 2001, 44pp.

Hillis, W.E., Sumimoto, M., 1989. Effect of extractives on pulping. In: Rowe, J.W. (Ed.), Natural Products of Woody Plants 1. Springer, Berlin, Heidelberg, New York, pp. 880-920.

Khristova, P., Kordsachia, O., Patt, R., Dafaalla, S., 2006. Alkaline pulping of some eucalypts from Sudan. Biosour. Technol. 97 (4), 535-544, http://dx.doi.org/10.1016/j.biortech.2005.04.006.

Kibblewhite, R.P., 1999. Designer fibres for improved papers through exploiting genetic variation in wood microstructure. Appita J. 52 (6), 429-435.

Kibblewhite, R.P., McKenzie, C.J., 1999. Kraft fibre property variation among 29 trees of 15 year old Eucalyptus fastigata and comparison with E. nitens. Appita J. 52 (3), 218-225.

Kibblewhite, R.P., Riddell, M.J.C., 2000. Wood and kraft fibre property variation within and among nine trees of Eucalyptus nitens. Appita 53 (3), 237-244.

Kibblewhite, R.P., Riddell, M.J.C., Shelbourne, C.J.A., 2000a. Variation in wood, kraft fibre, and handsheet properties among 29 trees of Eucalyptus regnans, and comparison with E. nitens and E. fastigata. New Zealand. J. For. Sci. 30 (3) 458-474.

Kibblewhite, R.P., Johnson, B.I., Shelbourne, C.J.A., 2000b. Kraft pulp qualities of Eucalyptus nitens, E. globulus, and E. maidenii, at ages 8 and 11 years. New Zealand. J. For. Sci. 30 (3), 447-457.

Knapic, S., Pirralho, M., Louzada, J.L., Pereira, H., 2014. Early assessment of density features for 19 Eucalyptus species using X-ray microdensitometry in a perspective of potential biomass production. Wood Sci. Technol. 48 (1), 37-49, http://dx.doi.org/10.1007/s00226-013-0579-y.

Kordsachia, O., Wandinger, B., Patt, R., 1992. Some investigations on ASAM pulping and chlorine free bleaching of Eucalyptus from Spain. Holz Roh-Werkst. 50, 85-91, http://dx.doi.org/10.1007/BF02628679.

Kumar, A., Luma, R.K., Parveen, Kumar, V., 2010. Variability in growth characteristics for different genotypes of Eucalyptus tereticornis (SM.). J. For. Jpn. 21 (4), 487-491, http://dx.doi.org/10.1007/s11676-010-0103-2.

Little, K.M., Gardner, R.A.W., 2003. Coppicing ability of 20 Eucalyptus species grown at two high-altitude sites in South Africa. Can. J. For. Res. 33 (2), 181-189, http://dx.doi.org/10.1139/x02-170.

Lourenç, A., Gominho, J., Pereira, H., 2010. Pulping and delignification of sapwood and heartwood from Eucalyptus globulus. J. Pulp Paper Sci. 36 (3-4), 85-90.

Lourenço, A., Gominho, J., Marques, A.V., Pereira, H., 2013. Kraft pulping of Eucalyptus globulus heartwood and sapwood. J. Wood Chem. Technol. 33, 1-18, http://dx.doi.org/10.1080/02773813.2012.703284.
Malik, R.S., Dutt, D., Tyagi, C.H., Jindal, A.K., Lakharia, L.K., 2004. Morphological, anatomical and chemical characteristics of Leucaena leucocephala and its impact on pulp and paper making properties. J. Sci. Ind. Res. 63, 125133.

Miranda, I., Pereira, H., 2002. Variation pulpwood quality with provenances and site in Eucalyptus globulus. Ann. For. Sci. 59 (3), 283-291.

Moussaouiti, M.E., Bercha, B., Alves, E.F., Francis, R.C., 2012. Fraft pulping characteristics of three Moroccan Eucalypti: part 1. Physical and chemical properties of woods and pulps. Bioresources 7 (2), 1558-1568.

Neiva, D.M., Gominho, J., Pereira, H., 2014. Modeling and optimization of Eucalyptus globulus bark and wood delignification using response surface methodology. BioResouces 9 (2), 2907-2921.

Ogunwusi, A.A., 2012. Interaction effect of pulping variables and storage time on pitch deposit during kraft pulping of mixed hardwoods. Adv. Agric. Sci. Eng. Res. 2 (10), 406-413.

Ona, T., Sonoda, T., Ito, K., Shibata, M., Tamai, Y., Kojima, Y., Ohshima, J., Yokota, S., Yoshizawa, N., 2001. Investigation of relationships between cell and pulp properties in Eucalyptus by examination of within-tree property variations. Wood Sci. Technol. 35 (3), 229-243, http://dx.doi.org/10.1007/s002260100090.

Oudia, A., Simões, R., Queiroz, J., Ragauskas, A., 2004. Studies on the effect of laccase mediator biodelignification of Eucalyptus globulus kraft pulp. In: In: Proceedings III Congreso Iberoamericano de Investigación en Celulosa y Papel, Córdoba, Espanha, pp. 259-262.

Paavilainen, L., 2000. Quality-competitiveness of Asian short-fibre raw materials in different paper grades. Paperi ja Puu 82 (3), 156-161.

Pereira, H., 1988. Variability in the chemical composition of plantation eucalypts (Eucalyptus globulus Labill). Wood Fiber Sci. 20 (1), 82-90.

Pereira, H., Miranda, I., Tavares, F., Quilhó, T., Graça, J., Rodrigues, J., Shatalov, A., Knapic, S., 2011. Qualidade e utilização tecnológica do eucalipto (Eucalyptus globulus). Centro de Estudos Florestais, Lisbon, ISBN 978-972-97874-3-0.

Pirralho, M., Flores, D., Sousa, V.B., Quilhó, T., Knapic, S., Pereira, H., 2014 Evaluation on paper making potential of nine Eucalyptus species based on wood anatomical features. Ind. Crop. Prod. 54, 327-334, http://dx.doi.org/10.1016/j.indcrop.2014.01.040.

Rahmati, H., Navaee-Ardeh, S., Aminian, H., 2007. Influence of sulfidity and active alkali charge on the properties of pulp produced from Eucalyptus camaldulensis. J. Plant Sci. 2 (6), 600-606, http://dx.doi.org/10.3923/jps.2007.600.606.

Rockwood, L.D., Rudie, W.A., Ralph, S.A., Zhu, Y.J., Winandy, E.J., 2008. Energy product options for Eucalyptus species grown as short rotation woody crops. Int. J. Mol. Sci. 9 (8), 1361-1378, http://dx.doi.org/10.3390/ijms9081361.

Santos, A., Amaral, M.E., Vaz, A., Anjos, O., Simões, R., 2008. Effect of Eucalyptus globulus wood density on papermaking potential. TAPPI J. 7 (5), 2532.

Silvy, J., Romatier, G., Chiodi, R., 1968. Méthodes pratiques de contrôle du raffinage. ATIP 22 (1), 31-53.

Spiridon, I., Popa, V.I., 2004. Hemicelluloses: structure and properties. In: Dumitriu, S. (Ed.), Polysaccharides Structural Diversity and Functional Versatility. CRC Press, New York, pp. 475-490.

Terdwongworakul, A., Punsuwan, V., Thanapase, W., Tsuchikawa, S., 2005. Rapid assessment of wood chemical properties and pulp yield of Eucalyptus camaldulensis in Thailand tree plantations by near infrared spectroscopy for improving wood selection for high quality pulp. J. Wood Sci. 51 (2), 167-171, http://dx.doi.org/10.1007/s10086-004-0633-3.

Wimmer, R., Downes, G.M., Evans, R., Rasmussen, G., French, J., 2002. Direct effects of wood characteristics on pulp and handsheet properties of Eucalyptus gobulus. Holzforschung 56 (3), 244-252. 